\title{
MINAS-TYPE FRESH CHEESE DEVELOPED FROM BUFFALO MILK WITH ADDITION OF L. ACIDOPHILUS
}

\author{
Bruna Marcatti ${ }^{1}$; Ana Mônica Quinta Barbosa Habitante ${ }^{1}$; Paulo José do Amaral Sobral ${ }^{1}$; \\ Carmen Sílvia Favaro-Trindade ${ }^{1 *}$ \\ ${ }^{1}$ USP/FZEA - Depto. de Engenharia de Alimentos, Av. Duque de Caxias Norte, 225, C.P. 23 - 13635-900 - \\ Pirassununga, SP - Brasil. \\ ${ }^{2}$ USP/FZEA - Graduanda em Engenharia de Alimentos. \\ *Corresponding author <carmenft@usp.br>
}

\begin{abstract}
Effective incorporation of a probiotic into foods requires the culture to remain viable all along processing and storage, without adverse alterations to sensory characteristics. The objective of this work was developing Minas-type fresh cheese with probiotic properties from buffalo milk. Four batches of Minas-type fresh cheese were prepared using buffalo milk: batch T1 in which neither culture nor lactic acid added; batch T3 in which only lactic acid added; batches T2 and T4 , both added of Lactobacillus acidophilus LAC 4, but T4 was also acidified. Resulting cheeses were evaluated for probiotic culture stability, texture profile, sensory acceptance, and changes in $\mathrm{pH}$. The T4 probiotic cheese presented hardness, gumminess, and chewiness significantly lower than the other treatments. However, values for springiness and cohesiveness did not differ between all cheeses, and no sensory differences $(p>0.05)$ were found between treatments for texture, taste, and overall acceptance. The addition of probiotic to the acidified cheese (T4) yielded best aroma. The populations of L. acidophilus were greater than $10^{6} \mathrm{CFU} \mathrm{g}^{-1}$ after 28 days of storage all products. Minas-type fresh cheese from buffalo milk is a suitable food for the delivery of L. acidophilus, since the culture remained viable during the shelf life of the products and did not negative affect analysed parameters.
\end{abstract}

Key words: Lactobacillus acidophilus, probiotic viability, sensory evaluation, texture

\section{DESENVOLVIMENTO DE QUEIJO MINAS FRESCAL DE LEITE DE BÚFALA COMADIÇÃO DE L.ACIDOPHILUS}

\begin{abstract}
RESUMO: Para incorporação efetiva de probióticos em alimentos é imprescindível que a cultura mantenha-se viável durante todo o processamento e a estocagem e que não ocorram alterações adversas nas características sensoriais do produto. O objetivo deste trabalho foi desenvolver queijo Minas frescal com propriedades probióticas a partir do leite de búfala. Foram avaliados quatro tratamentos (T1 a T4), sendo T1 e T3 controles, sem e com acidificação, respectivamente em T2 e T4 foram adicionados da cultura probiótica Lactobacillus acidophilus (LAC 4), porém T4 foi também acidificado. Todos os queijos foram avaliados quanto ao perfil de textura, aceitação sensorial e evolução do $\mathrm{pH}$. Nos queijos dos tratamentos T2 e T4 foi determinada a viabilidade da cultura probiótica, durante 28 dias de estocagem refrigerada. O tratamento $\mathrm{T} 4$ apresentou valores para dureza, gomosidade e mastigabilidade menores que aqueles obtidos para os demais tratamentos. Não houve diferenças entre os tratamentos $(p>0.05)$ em relação à elasticidade, coesividade, assim como para os atributos textura, sabor e aceitação global. O tratamento adicionado de probiótico e ácido foi o melhor aceito em função do aroma. A população de L. acidophilus permaneceu maior que $10^{6} \mathrm{UFC}^{-1}$ depois de 28 dias de estocagem mesmo no produto acidificado. Queijo Minas frescal de leite de búfala é um alimento adequado para incorporação de $L$. acidophilus, uma vez que esta cultura permaneceu viável no mesmo durante seu "shelf-life" e não interferiu negativamente nos parâmetros analisados.
\end{abstract}

Palavras-chave: Lactobacillus acidophilus, viabilidade, avaliação sensorial, textura

\section{INTRODUCTION}

Modern consumers are increasingly health conscious, and expect their food to be healthy or even capable of preventing illness (Mattila-Sandholm et al., 2002). "Probiotics are live microorganisms which, when administered in adequate amounts, con- fer health benefits on the host" (FAO, 2002). Humans need to ingest $10^{6}-10^{9}$ viable probiotic cells per day to amass any beneficial effects (Lee \& Salminen, 1995). In addition, pleasant taste and good texture are essential for all dairy products, regardless of the "health message" they may carry (Saxelin et al., 1999). 
Cheese may offer certain advantages over yoghurttype products in terms of the ease of delivery of viable probiotics. The higher $\mathrm{pH}$, higher fat content, and more solid consistency of cheese may offer more protection for the probiotics in the gastrointestinal tract (Stanton et al., 1998).

Although several studies have tested the performance of many probiotic cultures in the production of bovine fresh cheeses (Roy et al., 1997; Vinderola et al., 2000; Buriti et al., 2005a and Buriti et al., 2005b), no work has been done on buffalo fresh cheeses. The use of buffalo milk in the production of Minas-type fresh cheese represents an interesting alternative for increasing the value of this raw material, since the Brazilian buffalo herd has shown extraordinary growth in recent decades (Teixeira et al., 2005). According to Zoccal (2007), the world production of buffalo milk grew $41.6 \%$ between 1995 to 2005 whilst that of cow milk increased only $14.3 \%$. In addition, buffalo milk has higher levels of fat, protein, total solids, calories, vitamin A, and calcium comparatively to cow milk (Verruma \& Salgado, 1994).

Minas cheese is a typical Brazilian fresh cheese, which presents high water activity, $\mathrm{pH}$ above 5.0, low salt content, and the absence of preservatives, offering excellent conditions for the survival and growth of probiotic organisms (Buriti et al., 2005a). The aim of this work was to develop Minas-type fresh cheese with probiotic properties from buffalo milk, to evaluate cheeses' texture and sensory properties, and to determine the viability of the probiotic organisms during 28 days of refrigerated storage.

\section{MATERIALAND METHODS}

Raw buffalo milk, commercial rennet (85\% bovine pepsin $+15 \%$ chymosin), lactic acid 85 g $100 \mathrm{~g}^{-1}$ foodgrade solution, and commercial freeze-dried probiotic culture of L. acidophilus LAC 4 (for direct vat inoculation) were used in the manufacture of the cheeses.

Four pilot-scale Minas-type fresh cheese manufacturing protocols (T1, T2, T3, and T4) were carried out $(\mathrm{n}=3)$. Eighty liters of milk were divided to prepare four equal batches of cheese at the same time, according to the protocol outlined in Figure 1. Cheeses T1 were manufactured without the addition of either culture or lactic acid. Cheeses T2 ( were manufactured with the addition of a probiotic culture of $L$. acidophilus $(0.7 \% \mathrm{w} / \mathrm{v})$. Cheeses T3 were pre-

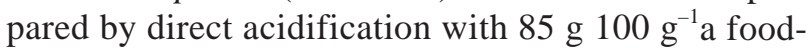
grade lactic acid solucion $\left(0.25 \mathrm{~mL} \mathrm{~L}^{-1}\right)$, and cheeses T4 were manufactured by direct acidification with lactic acid plus the addition of $L$. acidophilus $(0.7 \%$ $\mathrm{w} / \mathrm{v})$.

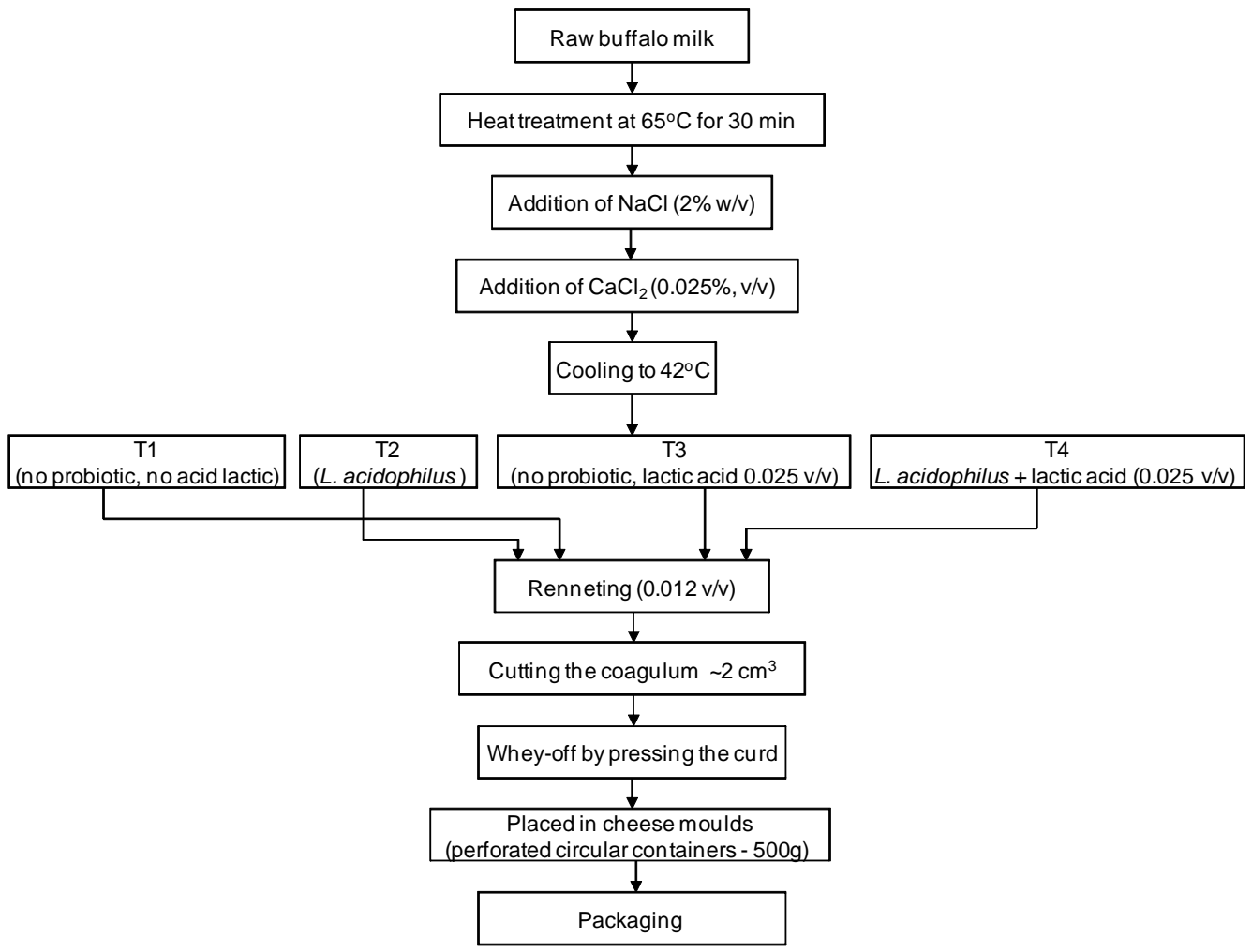

Figure 1 - Schematic diagram of Minas type fresh cheese production (T1: cheese with no probiotic and no lactic acid; T2: cheese with L. acidophilus; T3: cheese with lactic acid and no probiotic; T4: cheese with L. acidophilus and lactic acid). 
The cheeses were vaccum-packaged in plastic bags and stored under refrigeration $\left(7-9^{\circ} \mathrm{C}\right)$ for to 28 days. All cheese manufacturing trials and analyses, except sensory evaluation, were made in triplicate.

Texture properties of the cheeses were evaluated with the Texture Profile Analysis using a texturometer TA.XT2i, with a $20 \mathrm{~mm}$ diameter probe and $50 \%$ of sample deformation at a rate of $5 \mathrm{~mm} \mathrm{~s}^{-1}$, force of $0.2 \mathrm{~N}$, and time of $5 \mathrm{~s}$. These tests consisted of the two-bite compression of $2.0 \mathrm{~cm}$ sample cubes.

After cutting, cheese samples were refrigerated $\left(7^{\circ} \mathrm{C}\right)$ for $30 \mathrm{~min}$ prior to testing. Measured parameters were hardness, springiness, cohesiveness, chewiness, and gumminess, with the aid of the Texture Expert for Windows software version 1.20 (Stable Micro Systems). The TPA was carried out after one day of storage, and all measurements done in triplicate. The $\mathrm{pH}$ of cheeses was measured using a digital $\mathrm{pH}$ meter.

One day after manufacturing, samples of the T2 and T4 cheese batcheswere assessed for viability of the probiotic microorganisms (plate count). The products were also examined for probiotic cell viability at $7,14,21$, and 28 days of storage. Cheese samples (25 g) were serially diluted $(\mathrm{w} / \mathrm{w})$ with $2 \%$ citrate solution and then spread in duplicate onto MRS agar plateswhich were incubated at $37^{\circ} \mathrm{C}$ for $72 \mathrm{~h}$ under anaerobic conditions (Anaerobac System). The resulting colonies were counted and the total viable populations calculated per gram of the product (Grosso \& Favaro-Trindade, 2004).

The sensory evaluation was carried out in individual booths under a fluorescent white light with 46 untrained panellists selected according to willingness to participate. The consumer acceptance tests were conducted according to Meilgaard et al. (1999) for the evaluation of taste, aroma, texture, and overall acceptance. The samples were presented one at a time in plastic plates coded with random three digit numbers.

A nine-point, structured hedonic scale was used, ranging from "disliked extremely" (1) to "liked extremely" (9). The panellists were instructed to rinse their palate between samples. The samples were stored at $7^{\circ} \mathrm{C}$ in a refrigerator to maintain their integrity dur- ing the sensory analyses. The sensory evaluation was carried out after one day of storage.

Data obtained were statistically analyzed by SAS (2001), version 8.02, using the PROC ANOVA procedure. Tukey's Honestly Significant Difference test (HSD) $(\alpha=0.05)$ was adopted as the multiple comparisons procedure.

\section{RESULTS AND DISCUSSION}

\section{Texture profile}

Probiotic cheeses T2 were very similar to controls T1 and T3 in regard to texture parameters (Table 1). However, T4 cheeses presented lower hardness, chewiness, and gumminess values. Given that $\mathrm{T} 3$ and $\mathrm{T} 4$ cheeses presented similar $\mathrm{pH}$ after one day (Table 2), it is possible that a synergistic interaction between the $L$. acidophilus and the lactic acid produced cheeses with increased moisture. Hardness and its derivative texture parameters, i.e., chewiness and gumminess,are strongly influenced by cheeses' $\mathrm{pH}$ and moisture contents (Fox \& McSweeney, 1998).

Cheeses from the T4 batch were softer than the other cheese, requiring smaller compression force. T4 cheeses were also easier to swallow since they needed less chewing effort. Notwithstanding, the sensorial panellists were unable to detect significant differences in texture between samples (Table 4).

Several authors have recently tested the performance of various probiotic cultures in the production of different cheese types but only a few dealed with fresh cheeses, and none with fresh, buffalo milk cheese. Values recorded for hardness (4.32 to $3.92 \mathrm{~N}$ ), springiness $(0.88)$, chewiness (2.9 to $2.66 \mathrm{~N})$, and gumminess (3.33 to $3.03 \mathrm{~N}$ ) by Buriti et al. (2005a), working with fresh Minas-type cheese manufactured from cow milk containing a mesophilic culture and also with cheeses acidified with lactic acid, with and without $L$. acidophilus, were lower than the values registered in this study. The differences could be attributed to the fact that the proximate composition of buffalo milk and the concentration of the dry extract are completely different from that of cow milk (Verruma \& Salgado, 1994). In addition, Buriti et al. (2005a) also

Table 1 - Values obtained in the texture profile analysis. Analysis was carried out after one day of storage, in triplicate.

\begin{tabular}{lccccc}
\hline Treatments & Hardness $(\mathrm{N})$ & Springiness & Cohesiveness & Gumminess $(\mathrm{N})$ & Chewiness $(\mathrm{N})$ \\
\hline T1 & $9.72^{\mathrm{a}}$ & $0.99^{\mathrm{a}}$ & $0.44^{\mathrm{a}}$ & $4.29^{\mathrm{a}}$ & $4.26^{\mathrm{a}}$ \\
T2 & $11.44^{\mathrm{a}}$ & $0.97^{\mathrm{a}}$ & $0.40^{\mathrm{a}}$ & $4.66^{\mathrm{a}}$ & $4.51^{\mathrm{a}}$ \\
T3 & $10.64^{\mathrm{a}}$ & $0.97^{\mathrm{a}}$ & $0.38^{\mathrm{a}}$ & $4.05^{\mathrm{a}}$ & $3.92^{\mathrm{a}}$ \\
T4 & $4.79^{\mathrm{b}}$ & $1.00^{\mathrm{a}}$ & $0.47^{\mathrm{a}}$ & $2.25^{\mathrm{b}}$ & $2.24^{\mathrm{b}}$ \\
\hline
\end{tabular}

*a,bMeans in the same column with different letters are different $(p<0.05)$. T1: cheese with no probiotic and no lactic acid. T2: cheese with L. acidophilus. T3: cheese with lactic acid and no probiotic. T4: cheese with L. acidophilus and lactic acid. 
used different texture parameters (samples with heights of $3 \mathrm{~cm}, 20 \%$ compression and a speed of 2.0 $\mathrm{mm} \mathrm{s}^{-1}$ ) for their measurements.

\section{Viability of $\boldsymbol{L}$. acidophilus during cheese storage}

Effect of the refrigerated storage of Minas-type fresh cheese from buffalo milk on the viability of the probiotic microorganisms are shown on Table 3 . The initial counts ranged from $10^{7}$ to $10^{6} \mathrm{CFU} \mathrm{g}^{-1}$ for treatments T2 and T4, respectively, with negligible tendency to decrease throughout the storage period for treatment T2. However, this reduction was only significant $(p<0.05)$ between the values determined for days 1 and 28, being 0.76 of a logarithmic cycle. This result differed from that of Buriti et al. (2005a), where the population of $L$. paracasei increased approximately 2 logarithmic cycles during the 21 days of storage of fresh Minas-type cheeses produced from cow milk. However, the results were similar to that of Buriti et al. (2005b), who reported a population of L. acidophilus showing practically no alteration during a 21day storage of fresh Minas-type cheese made from cow milk. It is fair to infer that in comparison to $L$. paracasei, L. acidophilus was unable to multiply in fresh, refrigerated cheeses.

The counts for treatment T2 were higher $(p<0.05)$ at day one probably because the culture found better conditions in which to multiply while the cheeses were prepared, because the $\mathrm{pH}$ values were higher during preparation. After 21 days of storage, T4 cheeses counts were slightly below the threshold level $\left(10^{6} \mathrm{CFU} \mathrm{g}^{-1}\right), 5.96 \log \mathrm{CFU} \mathrm{g}{ }^{-1}$. Except for this point, both treatments had counts higher than $10^{6} \mathrm{CFU}$ $\mathrm{g}^{-1}$, which is the minimum value recommended for a product to have beneficial health effects. These results were similar to those reported by Vinderola et al. (2000), Yilmaztekin et al. (2004), Kasimoglu et al. (2004), Buriti et al. (2005a), and Buriti et al. (2005b).

The main causes of viability loss in probiotic microorganisms during cheeses storage are associated

Table 2 - Changes in the mean pH values in the different trials with Minas-type fresh cheese during storage at $7^{\circ} \mathrm{C}$.

\begin{tabular}{lcccc}
\hline \multirow{2}{*}{ Time (day) } & \multicolumn{4}{c}{ Treatments } \\
\cline { 2 - 5 } & T1 & T2 & T3 & T4 \\
\hline 1 & $6.71^{\mathrm{a}}$ & $6.65^{\mathrm{a}}$ & $6.21^{\mathrm{a}}$ & $6.23^{\mathrm{a}}$ \\
7 & $6.62^{\mathrm{a}}$ & $6.40^{\mathrm{b}}$ & $6.20^{\mathrm{a}}$ & $6.18^{\mathrm{a}}$ \\
14 & $6.41^{\mathrm{b}}$ & $5.98^{\mathrm{c}}$ & $6.15^{\mathrm{a}}$ & $5.55^{\mathrm{b}}$ \\
28 & $6.38^{\mathrm{b}}$ & $5.69^{\mathrm{d}}$ & $5.28^{\mathrm{b}}$ & $5.33^{\mathrm{c}}$ \\
\hline
\end{tabular}

a,b Means in the same column with different letters are different $(p<0.05)$. T1: cheese with no probiotic and no lactic acid. T2: cheese with $L$. acidophilus. T3: cheese with lactic acid and no probiotic. T4: cheese with $L$. acidophilus and lactic acid. with injuries caused by oxygen and salt toxicity. According to Yilmaztekin et al. (2004), the dissolved oxygen in cheese almost completely disappears within twothree weeks after manufacturing, providing suitable growth conditions for anaerobic microorganisms, and according to Buriti (2005a), fresh Minas-type cheeses ordinarily have low salt concentrations.

For the T4 cheeses, there was a decrease $(p<0.05)$ in the CFU counts at 21 days, however, there was no difference $(p<0.05)$ in CFU counts between 0 and 28 days. These fluctuations in cell numbers at certain points during storage, such as on the $21^{\text {th }}$ day for treatment $\mathrm{T} 4$, could be bias inherent to microbiological analyses. Considering that CFU are counted in these analyses and that a colony usually represents more than one microorganism, the microorganisms can either remain chained together or disaggregate during the shaking carried for preparation of dilutions, causing small variations.

Fermented dairy products are generally considered to be one of the most suitable vehicles for the administration of an adequate number of probiotic bacteria to consumers. Although still a matter of debate, several authors have indicated that a minimal concentration of $1 \times 10^{6} \mathrm{CFU} \mathrm{g}{ }^{-1}$ of the product is required to exert a probiotic effect (Ravula \& Shah, 1998; Shah, 2000 and 2001). The results obtained in the present work indicated that Minas-type fresh cheese manufactured from buffalo milk is a good vehicle for the delivery of L. acidophilus LAC4, which stood tough the conditions used to prepare and storage this cheese.

\section{Sensory evaluation}

Scores for the acceptance of the fresh Minas cheeses manufactured from buffalo milk are presented in Table 4. Samples showed good general acceptance for all the attributes. Aroma was the least accepted attribute for all treatments. This result was similar to that

Table 3 - Viability of L. acidophilus in the T2 and T4 buffalo milk Minas-type fresh cheeses during storage at $7^{\circ} \mathrm{C}$.

\begin{tabular}{lcc}
\hline \multirow{2}{*}{ Time (day) } & \multicolumn{3}{c}{ L. acidophilus counts $\left(\log 10\right.$ of CFU g $\left.^{-1}\right)$} \\
\cline { 2 - 3 } & \multicolumn{1}{c}{$\mathrm{T} 2$} & $\mathrm{~T} 4$ \\
\hline 1 & $7.22^{\mathrm{aA}}$ & $6.16^{\mathrm{abB}}$ \\
7 & $7.03^{\mathrm{abA}}$ & $6.16^{\mathrm{abB}}$ \\
14 & $6.59^{\mathrm{abA}}$ & $6.37^{\mathrm{aA}}$ \\
21 & $6.64^{\mathrm{abA}}$ & $5.96^{\mathrm{bB}}$ \\
28 & $6.46^{\mathrm{bA}}$ & $6.23^{\mathrm{abA}}$ \\
\hline
\end{tabular}

a,b Means in the same column with different letters are different $(p<0.05)$. ${ }^{\mathrm{A}, \mathrm{B}}$ Means in the same line with different letters are different $(p<0.05)$. T2: cheese with L. acidophilus. T4: cheese with $L$. acidophilus and lactic acid 
Table 4 - Mean scores obtained in the sensory analysis for aroma, texture, taste, and overall acceptance.

\begin{tabular}{lcccc}
\hline Treatments & Aroma & Texture & Taste & $\begin{array}{c}\text { Overall } \\
\text { acceptance }\end{array}$ \\
\hline T1 & $6.22^{\mathrm{ab}}$ & $7.28^{\mathrm{a}}$ & $7.22^{\mathrm{a}}$ & $7.17^{\mathrm{a}}$ \\
$\mathrm{T} 2$ & $6.11^{\mathrm{b}}$ & $7.15^{\mathrm{a}}$ & $7.37^{\mathrm{a}}$ & $7.24^{\mathrm{a}}$ \\
T3 & $6.89^{\mathrm{a}}$ & $7.57^{\mathrm{a}}$ & $7.54^{\mathrm{a}}$ & $7.46^{\mathrm{a}}$ \\
T4 & $6.80^{\mathrm{ab}}$ & $7.11^{\mathrm{a}}$ & $7.41^{\mathrm{a}}$ & $7.35^{\mathrm{a}}$ \\
\hline
\end{tabular}

*a,b Means in the same column with different letters are different $(p<0.05)$. *Scores were based on a 9 point hedonic scale with 1 as "disliked extremely" and 9 as "liked extremely." T1: cheese with no probiotic and no lactic acid. T2: cheese with $L$. acidophilus.T3: cheese with lactic acid and no probiotic. T4: cheese with $L$. acidophilus and lactic acid.

obtained for ice creams made with probiotic cultures (Favaro-Trindade et al., 2006).

Although the instrumental texture assay indicated that T4 cheeses were softer, less gummy, and easier to chew than the other cheeses (Table 2), this effect was probably not noticed by the panellists. Even if it was noticed, it was considered neither a defect nor a benefit, since the sensory analysis indicated no difference $(p>0.05)$ between the treatments for the attribute texture (Table 5).

Cheeses from all treatments also did not differ $(p>0.05)$ for the attributes taste and overall acceptance. It is thus fair to infer that the addition of $L$. acidophilus LAC 4 to Minas-type cheese manufactured from buffalo milk did not influence its sensory characteristics. This result is similar to that obtained for fresh cheeses made from cow milk by Alegro (2003), Kasimoglu et al. (2004), and Buriti et al. (2005b).

\section{ACKNOWLEDGMENTS}

To Conselho Nacional de Desenvolvimento Científico e Tecnológico (CNPq) for the scholarship awarded to Bruna Marcatti; Danisco for providing the probiotic cultures, and the Prefeitura do Campus Administrativo de Pirassununga da USP (PCAPS) for providing the buffalo milk.

\section{REFERENCES}

ALEGRO, J.H.A. Desenvolvimento de queijo Minas frescal probiótico com Lactobacillus acidophilus e Bifidobacterium lactis isolados e em co-cultura. São Paulo: USP/FCF, 2003. 84p. Dissertação (Mestrado).

BURITI, F.C.A.; ROCHA, J.S.; ASSIS, E.G.; SAAD, S.M.I. Probiotic potential of Minas fresh cheese prepared with the addition of Lactobacillus paracasei. LWT-Food Science and Technology, v.38, p.173-180, 2005a.

BURITI, F.C.A.; ROCHA, J.S.; SAAD, S.M.I. Incorporation of Lactobacillus acidophilus in Minas fresh cheese and its implications for textural and sensorial properties during storage. International Dairy Journal, v.15, p.1279-1288, 2005b.
FOOD AND AGRICULTURE ORGANIZATION - FAO. Guidelines for the evaluation of probiotics in food. Rome: FAO, 2002. 11p. Available at http://www.who.int/foodsafety/fs_management/ en/probiotic_guidelines.pdf. Accessed 6 Jul. 2007.

FAVARO-TRINDADE C.S.; BERNARDI S.; BODINI R.B.; BALIEIRO J.C.C.; ALMEIDA E. Sensory acceptability and stability of probiotic microorganisms and vitamin $C$ in fermented acerola (Malpighia emarginata DC.) ice cream. Journal of Food Science, v.71, p.492-495, 2006.

FOX, P.F.; McSWEENEY, P.L.H. Dairy chemistry and biochemistry. London: Blackie Academic \& Professional, 1998. 496p.

GROSSO, C.R.F.; FAVARO-TRINDADE, C.S. Stability of free and immobilized Lactobacillus acidophilus and Bifidobacterium lactis in acidified milk and immobilized B. lactis in yoghurt. Brazilian Journal of Microbiology, v.35, p.151-156, 2004.

KASIMOGLU, A.; GÖNCÜGLU, M.; AKGÜN S. Probiotic white cheese with Lactobacillus acidophilus. International Dairy Journal, v.14, p.1067-1073, 2004.

LEE, Y.K.; SALMINEN, S. The coming of age of probiotics. Trends in Food Science and Technology, v.6, p.241-244, 1995.

MATTILA-SANDHOLM, T.; MYLLARINEN, P.; CRITTENDEN, R.; MOGENSEN, G.; FONDEN, R.; SAARELA, M. Technological challenges for future probiotic foods. International Dairy Journal, v.12, p.173-182, 2002.

MEILGAARD, M.; CIVILLE, G.V.; CARR, B.T. Sensory evaluation techniques. Boca Raton: CRC-Press, 1999. 387p.

RAVULA, R.R.; SHAH, N.P. Selective enumeration of Lactobacillus casei from yoghurts and fermented milk drinks. Biotechnology Techniques, v.12, p.819-822, 1998.

ROY, D.; MAINVILLE, I.; MONDOU, F. Selective enumeration and survival of bifidobacteria in fresh cheese. International Dairy Journal, v.7, p.785-793, 1997.

SAS INSTITUTE. SAS/Stat software: release 8.02. Cary: SAS Institute, 2001.

SAXELIN, M.; GRENOV, B.; SVENSSON, U.; FONDEN, R.; RENIERO, R.; MATTILA-SANDHOLM, T. The technology of probiotics. Trends in Food Science \& Technology, v.10, p.387-392, 1999.

SHAH, N.P. Functional foods from probiotics and prebiotics. Food Technology. v.55, p.46-53, 2001.

SHAH, N.P. Probiotic bacteria: selective enumeration and survival in dairy foods. Journal of Dairy Science. v.83, p.894-907, 2000.

STANTON, C.; GARDINER, G.; LYNCH, P.B.; COLLINS, J.K.; FITZGERALD, G.; ROSS, R.P. Probiotic cheese. International Dairy Journal, v.8, p.491-496, 1998.

TEIXEIRA, L.V.; BASTIANETTO, E.; OLIVEIRA, D.A.A. Leite de búfala na indústria de produtos lácteos. Revista Brasileira de Reprodução Animal, v.29, p.96-100, 2005.

VERRUMA, M.R.; SALGADO, J.M. Chemical analysis of buffalo milk in relation to cow milk. Scientia Agricola, v.51, p.131137, 1994.

VINDEROLA, C.G.; PROSELLO, W.; GHIBERTO, D.; REINHEIMER, J.A. Viability of probiotic (Bifidobacterium, Lactobacillus acidophilus and Lactobacillus casei) and nonprobiotic microflora in Argentincan fresco cheese. Journal of Dairy Science, v.83, p.1905-1911, 2000.

YILMAZTEKIN, M.; ÖZER, B.H.; ATASOY, F. Survival of Lactobacillus acidophilus LA-5 and Bifidobacterium bifidum BB02 in white-brined cheese. International Journal of Food Sciences and Nutrition, v.55, p.53-60, 2004.

ZOCCAL, R. Produção mundial de leite de diferentes espécies de animais, 1995-2005. Available at: http://www.cnpgl.embrapa.br/ producao/dados2002/producao/tabela0210.php. Accessed 6 Jul. 2007.

Received July 16, 2007

Accepted September 26, 2008 